\title{
Peningkatan Kinerja Karyawan Melalui Integritas, Teamwork dan Employee Engagement Pada Bagian Lithographing di PT Doulton
}

\author{
Ende*, Nurilham Septyadin \\ Fakultas Ekonomi dan Bisnis, Universitas Bina Bangsa, Banten, Indonesia \\ Email: 1,"endefokus@gmail.com, ${ }^{2}$ Septiyadin@gmail.com \\ Email Penulis Korespondensi: endefokus@gmail.com \\ Submitted: 17/11/2021; Accepted: 26/11/2021; Published: 30/11/2021
}

\begin{abstract}
Abstrak-Kinerja karyawan pada PT Doulton terutama bagian Lithographing pada khususnya mengalami kendala dalam hal penurunan kuantitas kerja yang dapat mengakibatkan menurunnya kinerja serta dapat mengakibatkan menurunya produksi pada perusahaan. Penelitian ini bertujuan untuk mengkaji dan mengetahui pengaruh antara Integritas, Teamwork, Employee Engagement dengan Kinerja Karyawan pada Bagian Lithographing di PT Doulton. Jumlah populasi sebanyak 105 karyawan dan sampel penelitian sebanyak 83 orang karyawan. metode penelitian ini adalah metode deskriptif asosiatif. Berdasarkan analisis penelitian didapatkan nilai sebagai berikut; perhitungan dalam bentuk koefisien determinasi $\left(\mathrm{R}^{2}\right)$ memiliki nilai sebesar 38,9\%. Hasil uji hipotesis - $\mathrm{t}$ yaitu variabel integritas memperoleh nilai sebesar 4,667, teamwork memperoleh nilai sebesar 2,573, employee engagement memperoleh nilai sebesar 4,358, di mana lebih besar dari tabel sebesar 1,990 dan nilai sig. lebih kecil dari 0,05. Hasil penelitian secara simultan mendapatkan hasil sebagai berikut; $F_{\text {hitung }}$ sebesar 16,780 lebih besar dari $F_{\text {tabel }}$ sebesar 2,720. hasil penelitian dapat disimpulkan bahwa hubungan antara variabel Integritas, Teamwork, dan Employee Engagement secara parsial dan simultan terhadap Kinerja Karyawan memiliki hubungan pengaruh yang positif bahkan sangat signifikan.
\end{abstract}

Kata Kunci: Integritas; Teamwork; Employee Engagement; Kinerja Karyawan

\begin{abstract}
Employee performance in PT Doulton especially Lithographing part in particular experienced constraint in the case of decreasing the quantity of work that could result in decreased performance and could result in declining production in Company. This research is direction investigation and knowing the influence between Integrity, Teamwork, Employee Engagement with Employee Performance in the lithographing section at PT Doulton. The total population is 105 employees and the study sample is 83 employees. this method of research is an associative descriptive method Based on research analysis obtained the results values; Calculations in the form of coefficient of determination $\left(\mathrm{R}^{2}\right)$ have a value of 38,9\%. The-t hypothesis test result of an integrity variable earns a value of 4,667 , teamwork earns a value 2,573 , employee engagement earns a value 4,358 , which is greater than 1,990 and the value of sig. Smaller than 0,05 . The results of simultaneous research get the following results; $F_{\text {count }}$ of 16,780 is greater than the $\mathrm{f}_{\text {table }}$ of 2,720. the research results can be concluded that the relationship between integrity variables, Teamwork, and Employee Engagement is partial and simultaneous to performance Employees have a positive influence that is even very significant.
\end{abstract}

Keywords: Integrity; Teamwork; Employee Engagement; Employee Performance

\section{PENDAHULUAN}

Dalam rangka menghadapi era globalisasi saat ini kemajuan ilmu pengetahuan dan teknologi di negara maju maupun berkembang sangat ditentukan oleh perkembangan Manajemen Sumber Daya Manusia (MSDM), sering disebut Human Resource Management yang merupakan faktor dominan disegala bidang. Disisi lain perkembangan tersebut tidak seluruhnya berdampak positif. Peningkatan kualitas manajemen sumber daya manusia yang dilihat dari konsep totalitas kehidupan perlu dilengkapi dengan dimensi kualitas yang bersifat strategis dalam konteks pembangunan seluruhnya, yaitu keimanan dan ketakwaan kepada Tuhan Yang Maha Esa, profesional, intelektual, disiplin dan efisiensi.

Kondisi terkait kinerja karyawan pada PT Doulton terutama bagian Lithographing pada khususnya mengalami kendala dalam hal penurunan kuantitas kerja yang dapat mengakibatkan menurunnya kinerja serta dapat mengakibatkan menurunya produksi pada perusahaan. Hal demikian terjadi memang karena kondisi perusahaan yang sedang tidak stabil diakibatkan fokus perusahaan pada barang-barang yang berjangka waktu panjang dalam proses produksinya. Contohnya barang-barang yang tidak memiliki motif (polos putih), sedangkan bagian Lithographing yang memproduksi barang-barang bermotif untuk proses produksinya yang lebih mendominasi. Kualitas kerja karyawan juga mendapat sorotan bagi penulis untuk diteliti. Karena belakangan ini kualitas kerja menurun di bagian Lithographing terutama dalam beberapa barang yang harus memiliki kualitas yang baik. Hal itu dibuktikan dengan banyaknya temuan hasil kerja yang tidak memenuhi standar kualitas bahkan ada juga barang yang failed yang harus dihancurkan.

Berdasarkan hasl observasi teramati bahwa litho fault (barang yang dihancurkan/rejek) mengalami kenaikan dari bulan Maret sebesar 31\% dan bulan April 36\% yang berarti mengalami kenaikan sebesar 5\%. dan untuk target produksi bagian lithographing belum mencapai target yang diinginkan perusahaan yaitu sebesar 12,376 pcs. perhari, dimana hanya tercapai rata-rata 6,150 pcs. perhari pada bulan Maret dan pada bulan April hanya tercapai rata-rata 5,332 pcs. perhari dan hal itu pun mengalami penurunan dalam segi kuantitas karyawan. Dalam hal kualitas karyawan juga mengalami penurunan yang sebelumnya pada bulan Maret 107.9\% menurun menjadi 107.8\% pada bulan April, memang hanya beda beberapa digit saja tetapi itu sangat berpengaruh karena yang seharusnya ada progres yang lebih baik untuk kualitas karyawan tetapi mengalami penurunan.

Menurut Yusnaena dan Syarif (2013:191) untuk meningkatkan Kinerja Karyawan dilakukan dengan memperbaiki Integritas para karyawan, karena dalam penelitiannya Integritas sangat berpengaruh terhadap meningkatkan Kinerja Karyawan. Dalam penelitian yang dilakukan oleh Agata Cristine Panggaki dkk. (2017:3019) 
menjelaskan bahwa dalam meningkatkan Kinerja Karyawan perlunya Teamwork dan itu sangat berpengaruh signifikan. Adapun menurut Nurfajar, M. Syafiq Marzuqi, Nika Rohmayati (2018) dalam penelitiannya menjelaskan bahwa untuk meningkatkan Kinerja Karyawan salah satunya dengan Employee Engagement.

\section{METODE PENELITIAN}

\subsection{Kinerja Karyawan}

Menurut Malayu Hasibuan (2012:94) Kinerja karyawan merupakan suatu hasil kerja yang dicapai seseorang dalam melaksanakan tugas-tugas diberikan kepadanya yang didasarkan atas kecakapan pengalaman dan kesungguhan serta waktu. Menurut Lijan Poltak Sinambela (2012:5) Kinerja karyawan didefinisikan sebagai kemampuan karyawan dalam melakukan suatu keahlian tertentu. Menurut Pandi Afandi (2016:69) kinerja adalah sejauh mana seseorang telah memainkan baginya dalam melaksanakan strategi organisasi, baik dalam mencapai sasaran khusus yang berhubungan dengan peran perorangan dan atau dengan memperlihatkan kompetensi yang dinyatakan relevan bagi organisasi

\subsection{Dimensi Kinerja Karyawan}

Menurut Viswesvaran, Chockalingam \& Ones, Deniz S. (2000) menjelaskan indikator variabel yang akan dijadikan dasar untuk membuat butir-butir pernyataan dalam instrumen penelitian. Oleh karena itu dimensi dan indikator kinerja karyawan meliputi:

a. Effort, jumlah usaha dalam kerja nyata yang diperlihatkan oleh karyawan dalam upayanya menyelesaikan pekerjaan yang dapat dilihat dari inisiatif dan giat tidaknya seorang karyawan dalam bekerja.

b. Job Knowledge, luas pengetahuan mengenai pekerjaan dan keterampilan yang dimiliki karyawan, dapat ditinjau dari kemampuan pegawai dalam memahami hal-hal yang berkaitan dengan tugas yang mereka lakukan

c. Quality, seberapa baik karyawan menye-lesaikan pekerjaan

d. Quantity, merupakan jumlah pekerjaan yang diproduksi yang dinyatakan dalam nilai mata uang, jumlah unit produksi ataupun dalam jumlah siklus aktivitas yang telah terselesaikan

e. Compliance with rules, kepahaman dan kepatuhan karyawan terhadap aturan dan regulasi yang ada di dalam perusahaan.

f. Interpersonal competence, kemampuan seseorang untuk menjalin hubungan baik dengan orang lain serta kemampuan untuk bekerja sama dengan rekan kerja lainnya.

\subsection{Integritas}

Menurut Yusnaena, dan Sahril (2013) Integritas yaitu bertindak konsisten sesuai dengan nilai-nilai dan kebijakan organisasiserta kode etik profesi, walaupun dalam keadaan yang sulit untuk melakukan ini. Menurut Ulfah Indri Utami (2015) Integritas merupakan kepatuhan tanpa kompromi untuk kode nilai-nilai moral, dan menghindari penipuan, kemanfaatan, kepalsuan, atau kedangkalan apapun. Menurut Anitaria, Mikha (2011) Integritas juga dapat diartikan sebagai kejujuran dan kebenaran dari tindakan seseorang dalam kehidupan sehari-hari.

Berdasarkan uraian diatas dari beberapa konsep tentang semua pengertian mengenai Integritas yang sebagaimana telah dikemukakan oleh para ahli, maka dapat ditarik kesimpulan bahwa Integritas adalah suatu karakter yang harus dimiliki oleh seseorang dalam menjunjung tinggi sifat jujur, berani, memiliki nilai-nilai, kode etik, etika dan moral untuk mejadi pribadi yang lebih baik dalam memajukan perusahaan.

\subsection{Dimensi Integritas}

Menurut Rogers, C.R., indikator integritas yaitu:

1. Jujur

Jujur berarti tidak mengingkari hati nurani, berbicara dan bertindak sesuai nilai-nilai pribadi yang dipegang teguh serta menjaga komitmen terhadap orang lain.

2. Teguh

Teguh artinya tidak menyalahi prinsip dalam menjalankan kewajiban, tidak dapat disuap atau diajak melakukan perbuatan curang meskipun ada godaan materi atau dorongan dari orang lain.

3. Memiliki self-control yang kuat

Self-control didefinisikan sebagai kemampuan individu dalam mengontrol atau memantau respon agar sesuai dengan tujuan hidup dan standar moral yang dimiliki.

\subsection{Teamwork}

Menurut Burn Shawn M., (2004) Teamwork merupakan sinergitas kekuatan dari beberapa orang dengan kompetensi yang setara, dimana mereka bekerja secara ketergantungan dalam melaksanakan pekerjaan di satu organisasi. Menurut James Campbell Q., and Debra L. Nelson (2011) Teamwork adalah proses bekerja dalam sebuah kelompok yang dengan kepemimpinan partisipatif, berbagi tanggung jawab, lurus dalam tujuan, komunikasi yang intensif, fokus ke masa depan, fokus pada tugas, bakat yang kreatif dan responsif untuk mencapai tujuan organisasi. Menurut Robbins, Stephen P., \& Timothy A. Judge. (2017) Teamwork adalah kelompok yang usaha-usaha individualnya menghasilkan 
kinerja lebih tinggi daripada hasil yang didapatkan jika pekerjaan diselesaikan seorang diri. Menurut Dewi Sandra (2007) indikator Teamwork adalah sebagai berikut:

1. Mau bekerjasama (cooperative)

2. Mengungkapkan harapan yang positif

3. Memberikan dorongan

4. Menghargai masukan

5. Membangun semangat kelompok

\subsection{Employee Engagement}

Menurut Macey, W.H., Schneider, B., Barbera, K.M. \& Young, S.A., (2009) Employee Engagement merupakan penghayatan seorang karyawan terhadap tujuan dan pemusatan energi, yang muncul dalam bentuk inisiatif, usaha, dan kegigihan yang mengarah pada tujuan organisasi. Menurut Truss, C., dkk., (2014) Employee Engagement didefinisikan sebagai keterikatan dan antusiasme karyawan terhadap pekerjaannya, menyamakan employee engagement dengan keterikatan emosional karyawan yang positif dalam komitmen karyawan. Menurut MacLeod, D. and Clarke, N. (2009) Employee Engagement didefinisikan umumnya sebagai pendekatan tempat kerja dirancang untuk memastikan bahwa karyawan berkomitmen pada tujuan dan nilai-nilai organisasi mereka, termotivasi untuk berkontribusi pada kesuksesan organisasi, dan sedang pada saat yang sama dapat meningkatkan rasa kesejahteraan mereka sendiri. Dimensi Employee Engagement

1. Vigor

Vigor melibatkan tingkat tinggi energi dan ketahanan mental saat bekerja.

2. Dedication

Dedication mengacu pada keterlibatan seseorang dalam pekerjaan dan mengalami rasa penuh makna, antusiasme, dan kebanggaan

3. Absorption

Absorption merupakan aspek yang mengacu pada konsentrasi dan keseriusan dalam bekerja, menikmati pekerjaan sehingga waktu terasa berlalu begitucepat ketika sedang bekerja dan merasa sulit melepaskan diri dari pekerjaan sehingga melupakan segala sesuatu disekitarnya.

\subsection{Kerangka Berfikir}

Kerangka pemikiran yang digunakan dalam penelitian ini terkait dengan keterikatan variabel-variabelnya dapat digambarkan sebagai berikut:

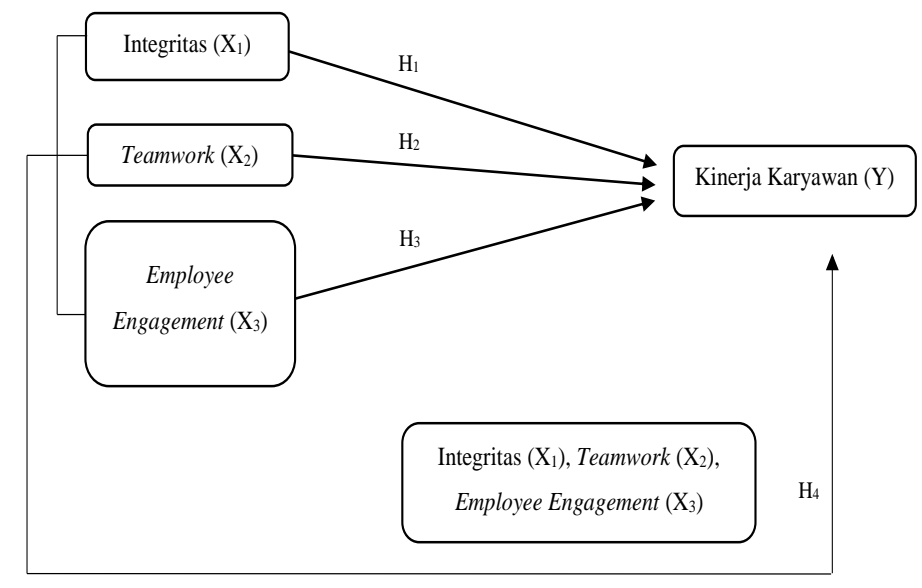

Gambar 1. Kerangka Berpikir

\subsection{Hipotesis Penelitian}

Berdasarkan kajian teoritis dan penyusunan kerangka berfikir dengan asumsi hubungan antara variabel bebas dengan variabel terikat baik secara terpisah maupun bersama-sama, maka penelitian mengajukan hipotesis penelitian sebagai berikut:

$\mathrm{H}_{1}=$ Integritas $\left(\mathrm{X}_{1}\right)$ berpengaruh terhadap Kinerja Karyawan $(\mathrm{Y})$

$\mathrm{H}_{2}=$ Teamwork $\left(\mathrm{X}_{2}\right)$ berpengaruh terhadap Kinerja Karyawan (Y)

$\mathrm{H}_{3}=$ Employee Engagement $\left(\mathrm{X}_{3}\right)$ berpengaruh terhadap Kinerja Karyawan $(\mathrm{Y})$

$\mathrm{H}_{4}=$ Integritas $\left(\mathrm{X}_{1}\right)$, Teamwork $\left(\mathrm{X}_{2}\right)$, Employee Engagement $\left(\mathrm{X}_{3}\right)$, berpengaruh terhadap Kinerja Karyawan $(\mathrm{Y})$.

Metode penelitian ini menggunakan metode deskriptif asosiatif, adalah suatu penelitian yang berusaha mencari hubungan antara dua variabel atau lebih. Hubungannya bisa simetris, kausal dan interaktif. Data yang tersedia akan dikelola dengan menggunakan SPSS versi 24. Sedangkan pendekatan lapangan yang diambil dengan menggunakan metode survei. 
Dalam penelitian ini, Digunakan penelitian kuantitatif dimana proses penggalian informasi diwujudkan dalam bentuk angka-angka sebagai alat untuk menemukan keterangan mengenai apa yang diketahui. Penelitian mengambil tempat di PT Doulton, Jalan Raya Serang KM. 29.9, Desa Gembong, Kecamatan Balaraja, Kabupaten Tangerang, Provinsi Banten, Kode Pos 15610. populasi yang akan dijadikan sampel yaitu semua karyawan yang bekerja pada bagian lithographing PT Doulton yaitu sebanyak 105 orang karyawan.

Berdasarkan perhitungan menggunakan rumus slovin, maka sampel yang layak digunakan adalah minimal 83,16 responden tapi dibulatkan menjadi 83 responden. Sehingga dalam penelitian ini penulis memutuskan untuk menggunakan 83 responden untuk diambil datanya melalui penyebaran kuesioner. Adapun keterangannya sebagai berikut:

Tabel 1. Data Karyawan

\begin{tabular}{|c|c|c|}
\hline Jabatan & $\begin{array}{l}\text { Jumlah } \\
\text { Orang }\end{array}$ & Keterangan \\
\hline Operator & 82 orang & Responden \\
\hline Shift Leader & 1 orang & Responden \\
\hline
\end{tabular}

\section{HASIL DAN PEMBAHASAN}

\section{Uji Validitas}

Suatu hasil penyebaran kuesioner pada pernyataan dinyatakan valid apabila setiap butir pernyataan menentukan nilai rhitung lebih besar dari rtabel. Adapun hasil dari uji validitas setiap variabel yaitu sebagai berikut:

Tabel 2. Hasil Uji Validitas

\begin{tabular}{|c|c|c|c|}
\hline Variabel & $\begin{array}{l}\text { Butir } \\
\text { Soal }\end{array}$ & $\begin{array}{c}\text { Corrected } \\
\text { Item-Total } \\
\text { Correla- } \\
\text { tion }\end{array}$ & $\begin{array}{c}\text { Keputusan }(\mathrm{r} \\
>2,159)= \\
\text { Valid }\end{array}$ \\
\hline \multirow{12}{*}{$\begin{array}{l}\text { Kinerja } \\
\text { Karyawan } \\
(\mathrm{Y})\end{array}$} & 1 & 0,623 & Valid \\
\hline & 2 & 0,773 & Valid \\
\hline & 3 & 0,595 & Valid \\
\hline & 4 & 0,730 & Valid \\
\hline & 5 & 0,553 & Valid \\
\hline & 6 & 0,495 & Valid \\
\hline & 7 & 0,681 & Valid \\
\hline & 8 & 0,494 & Valid \\
\hline & 9 & 0,706 & Valid \\
\hline & 10 & 0,393 & Valid \\
\hline & 11 & 0,526 & Valid \\
\hline & 12 & 0,681 & Valid \\
\hline \multirow{10}{*}{$\begin{array}{l}\text { Integritas } \\
\left(\mathrm{X}_{1}\right)\end{array}$} & 1 & 0,551 & Valid \\
\hline & 2 & 0,578 & Valid \\
\hline & 3 & 0,746 & Valid \\
\hline & 4 & 0,738 & Valid \\
\hline & 5 & 0,794 & Valid \\
\hline & 6 & 0,887 & Valid \\
\hline & 7 & 0,746 & Valid \\
\hline & 8 & 0,738 & Valid \\
\hline & 9 & 0,664 & Valid \\
\hline & 10 & 0,542 & Valid \\
\hline \multirow{8}{*}{$\begin{array}{l}\text { Teamwork } \\
\left(\mathrm{X}_{2}\right)\end{array}$} & 1 & 0,330 & Valid \\
\hline & 2 & 0,961 & Valid \\
\hline & 3 & 0,767 & Valid \\
\hline & 4 & 0,907 & Valid \\
\hline & 5 & 0,923 & Valid \\
\hline & 6 & 0,931 & Valid \\
\hline & 7 & 0,961 & Valid \\
\hline & 8 & 0,874 & Valid \\
\hline
\end{tabular}


Ekonomi, Keuangan, Investasi dan Syariah (EKUITAS)

Vol 3, No 2, November 2021, Hal 124-134

ISSN 2685-869X (media online)

DOI 10.47065/ekuitas.v3i2.1084

\begin{tabular}{lccc}
\hline Variabel & $\begin{array}{c}\text { Butir } \\
\text { Soal }\end{array}$ & $\begin{array}{c}\text { Corrected } \\
\text { Item-Total } \\
\text { Correla- } \\
\text { tion }\end{array}$ & $\begin{array}{c}\text { Keputusan }(\mathrm{r} \\
>2,159)= \\
\text { Valid }\end{array}$ \\
\hline Employee & 10 & 0,745 & Valid \\
Engage- & 1 & 0,625 & Valid \\
ment $\left(\mathrm{X}_{3}\right)$ & 2 & 0,584 & Valid \\
& 3 & 0,506 & Valid \\
& 4 & 0,689 & Valid \\
& 5 & 0,805 & Valid \\
& 6 & 0,645 & Valid \\
& 7 & 0,733 & Valid \\
& 8 & 0,447 & Valid \\
& 9 & 0,479 & Valid \\
& 10 & 0,733 & Valid \\
& 11 & 0,479 & Valid \\
& 12 & 0,352 & Valid \\
\hline
\end{tabular}

\section{Uji Reliabilitas}

Suatu data hasil penyebaran kuesioner pada pernyataan setiap variabel dinyatakan reliabel apabila setiap butir pernyataan menentukan nilai > 0,60. Adapun hasil uji reliabilitas adalah sebagai berikut:

Tabel 3. Uji Reliabilitas

\begin{tabular}{clcc}
\hline No. & \multicolumn{1}{c}{ Variabel } & $\begin{array}{c}\text { Cronbach } \\
\text { Alpha }\end{array}$ & $\begin{array}{c}\text { Keputusan }(\mathrm{r} \\
>0,06)= \\
\text { Reliabel }\end{array}$ \\
\hline 1 & Kinerja Karyawan $(\mathrm{Y})$ & 0,893 & Reliabel \\
2 & Integritas $\left(\mathrm{X}_{1}\right)$ & 0,920 & Reliabel \\
3 & Teamwork $\left(\mathrm{X}_{2}\right)$ & 0,955 & Reliabel \\
4 & Employee Engagement $\left(\mathrm{X}_{3}\right)$ & 0,891 & Reliabel \\
\hline
\end{tabular}

Uji Asumsi Klasik

\section{Uji Normalitas}

Uji normalitas dimaksudkan untuk mengetahui apakah residual yang diteliti berdistribusi normal atau tidak. Berikut merupakan hasil dari uji normalitas:

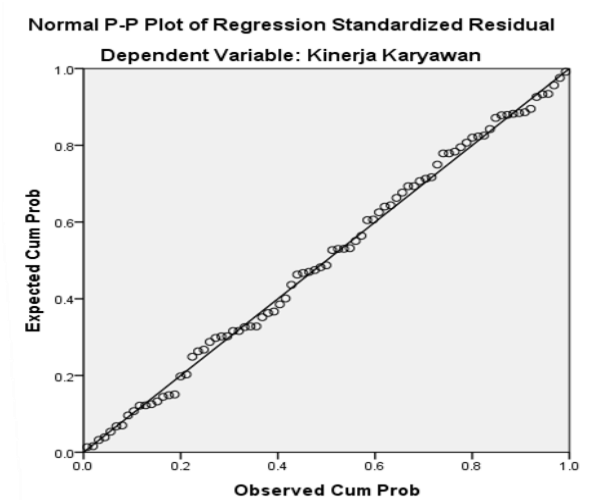

Gambar 2. Grafik P-P Plot Uji Normalitas

Berdasarkan Gambar 2 di atas, dapat dilihat pula data mengikuti arah garis diagonal. Hal tersebut berarti uji normalitas sudah terpenuhi atau model telah berdistribusi normal.

Model regresi yang baik memiliki distribusi data normal atau mendeteksi normal dengan melihat nilai signifikasi (Asymp. Sig. (2-tailed) yang menggunakan uji normalitas Kolmogorov-Smirnov. Hasil uji normalitas dapat dilihat pada tabel berikut: 
Ekonomi, Keuangan, Investasi dan Syariah (EKUITAS)

Vol 3, No 2, November 2021, Hal 124-134

ISSN 2685-869X (media online)

DOI 10.47065/ekuitas.v3i2.1084

Tabel 4. Uji Normalitas Kolmogorov-Smirnov

\begin{tabular}{|c|c|c|}
\hline \multicolumn{3}{|c|}{ One-Sample Kolmogorov-Smirnov Test } \\
\hline & & $\begin{array}{c}\text { Unstandardized } \\
\text { Residual }\end{array}$ \\
\hline $\mathrm{N}$ & & 83 \\
\hline Normal & Mean & 0,0000000 \\
\hline Parameters ${ }^{a}$ & Std. & 3,12687355 \\
\hline$b$ & Deviation & \\
\hline Most & Absolute & 0,048 \\
\hline Extreme & Positive & 0,047 \\
\hline Differences & Negative & $-0,048$ \\
\hline Test Statistic & & 0,048 \\
\hline Asymp. Sig. $(2$ & ailed) & $0,200^{\mathrm{c}, \mathrm{d}}$ \\
\hline a. Test distribut & is Normal. & \\
\hline b. Calculated $f r$ & data. & \\
\hline c. Lilliefors Sigr & ance Cor & \\
\hline d. This is a lowe & ound of the & gnificance. \\
\hline
\end{tabular}

Berdasarkan tabel 4 di atas, didapati output nilai signifikansinya adalah 0,200. Dapat disimpulkan bahwa nilai sig. > 0,05 maka data dapat dikatakan berdistribusi normal.

\section{Uji Heteroskedastisitas}

Uji heteroskedastisitas digunakan untuk mengetahui ada atau tidaknya penyimpangan asumsi klasik heteroskedastisitas yaitu adanya ketidaksamaan varian dari residual untuk semua pengamatan pada model regresi. Untuk mendeteksi apakah terdapat heteroskedostisitas atau tidak, dapat melihat grafik scatter plot di bawah ini.

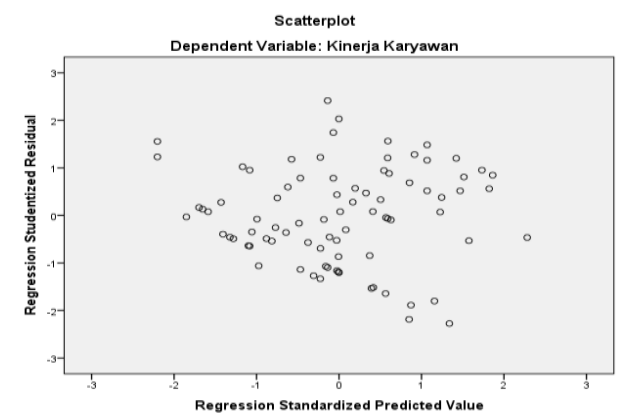

Gambar 3. Scatter Plot Uji Heteroskedastisitas

Terlihat bahwa titik-titik tersebar di atas dan di bawah garis nol pada sumbu vertikal sehingga dapat disimpulkan bahwa tidak terjadi heteroskedastisitas.

\section{Uji Multikolinieritas}

Uji multikolinieritas untuk mengetahui apakah pada model regresi ditemukan adanya korelasi antara variabel independen. Jika terjadi korelasi, terdapat masalah multikolinieritas yang harus diatasi. Di bawah ini merupakan hasil perhitungan multikolinieritas data, yaitu sebagai berikut:

Tabel 5. Uji Multikolinieritas

\begin{tabular}{|c|c|c|c|}
\hline \multicolumn{4}{|c|}{ Coefficients $^{a}$} \\
\hline \multicolumn{2}{|c|}{ Model } & \multicolumn{2}{|c|}{ Collinearity Statistics } \\
\hline & & Tolerance & VIF \\
\hline \multirow[t]{4}{*}{1} & (Constant) & & \\
\hline & Integritas & 0,985 & 1,016 \\
\hline & Teamwork & 0,982 & 1,018 \\
\hline & Employee Engagement & 0,967 & 1,034 \\
\hline
\end{tabular}

a. Dependent Variable: Kinerja Karyawan 
Berdasarkan Tabel 5 di atas, dapat diketahui bahwa variabel independen yaitu variabel integritas memiliki nilai VIF di bawah 10 jadi tidak terjadi gejala multikolinieritas.

\section{Analisis Korelasi Berganda (R)}

Berdasarkan hasil output pengujian pada SPSS versi 24 hasil dari variabel Integritas $\left(\mathrm{X}_{1}\right)$, Teamwork $\left(\mathrm{X}_{2}\right)$ dan Employee Engagement $\left(\mathrm{X}_{3}\right)$ terhadap Kinerja Karyawan (Y) adalah sebagai berikut:

Tabel 6. Output Korelasi Berganda

\begin{tabular}{|c|c|c|c|c|}
\hline Model Summary & \\
\hline Model & $\mathrm{R}$ & $\begin{array}{c}\mathrm{R} \\
\text { Square }\end{array}$ & $\begin{array}{c}\text { Adjusted } \\
\mathrm{R} \text { Square }\end{array}$ & $\begin{array}{c}\text { Std. Error of the } \\
\text { Estimate }\end{array}$ \\
\hline 1 & $0,624^{\mathrm{a}}$ & 0,389 & 0,366 & 3,186 \\
\hline a. Predictors: (Constant), Employee Engagement, Integritas, Teamwork \\
b. Dependent Variable: Kinerja Karyawan
\end{tabular}

Berdasarkan data Tabel 6 di atas, terlihat bahwa nilai R (Koefisien Korelasi) adalah 0,624. Nilai tersebut memang tidak begitu cukup besar namun dapat berpengaruh terhadap Y secara simultan. Hal tersebut mampu menjelaskan bahwa nilai yang dihasilkan dapat berkontribusi dalam keterikatan di antara variabel Dependent dan variabel Independent.

\section{Analisis Regresi Linier Berganda}

Berdasarkan hasil dari output perhitungan dari SPSS versi 24 untuk Regresi Linier Berganda adalah sebagai berikut:

Tabel 7. Output Analisis Regresi Linier Berganda

\begin{tabular}{llcc}
\hline & & \multicolumn{2}{c}{ Unstandardized } \\
& & Coefficients \\
& & $\mathrm{B}$ & Std. Error \\
\hline 1 & (Constant) & 1,644 & 5,745 \\
& Integritas & 0,439 & 0,094 \\
& Teamwork & 0,221 & 0,086 \\
& Employee Engagement & 0,383 & 0,088 \\
\hline
\end{tabular}

Keterangan :

Y : Kinerja Karyawan

a : 1,644

$\mathrm{b}_{1}: 0,439$

$\mathrm{b}_{2}: 0,221$

$\mathrm{b}_{3}: 0,383$

Sehingga dinyatakan dalam bentuk persamaan regresi sebagai berikut:

$\mathrm{Y}=\mathrm{a}+\mathrm{b}_{1} \mathrm{X}_{1}+\mathrm{b}_{2} \mathrm{X}_{2}+\mathrm{b}_{3} \mathrm{X}_{3}$

$\mathrm{Y}=1,644+0,439 \mathrm{X}_{1}+0,221 \mathrm{X}_{2}+0,383 \mathrm{X}_{3}$

Dari Tabel 7 dan persamaan regresi berganda di atas dapat disimpulkan bahwa:

a. Nilai konstanta 1,644 artinya apabila nilai Integritas, Teamwork dan Employee Engagement adalah nol maka nilai Kinerja Karyawan positif 1,644 .

b. Koefisien regresi $X_{1}$ variabel Integritas sebesar 0,439 (tanda positif) artinya setiap penambahan/peningkatan 1 satuan Integritas maka akan menaikkan Kinerja Karyawan sebesar 0,439 satuan, dan sebaliknya jika turun sebesar 1 satuan maka Kinerja Karyawan diprediksi mengalami penurunan sebesar 0,439 satuan.

c. Koefisien regresi $\mathrm{X}_{2}$ variabel Teamwork sebesar 0,221 (tanda positif) artinya setiap penambahan/peningkatan 1 satuan Teamwork maka akan menaikkan Kinerja Karyawan sebesar 0,221 satuan, dan sebaliknya jika turun sebesar 1 satuan maka Kinerja Karyawan diprediksi mengalami penurunan sebesar 0,221 satuan.

d. Koefisien regresi $\mathrm{X}_{3}$ variabel Employee Egagement sebesar 0,383 (tanda positif) artinya setiap penambahan/peningkatan 1 satuan Employee Egagement maka akan menaikkan Kinerja Karyawan sebesar 0,383 satuan ,dan sebaliknya jika turun sebesar 1 satuan maka Kinerja Karyawan diprediksi mengalami penurunan sebesar 0,383 satuan.

\section{Analisis Koefisien Determinasi $\left(\mathbf{R}^{2}\right)$}

Berdasarkan perhitungan koefisien korelasi maka didapati koefisien determinasi yaitu untuk melihat besarnya persentase $(\%)$ pengaruh variabel $\mathrm{X}$ terhadap variabel Y. Berikut merupakan nilai koefisien determinasi pada tabel di bawah ini: 
Ekonomi, Keuangan, Investasi dan Syariah (EKUITAS)

Vol 3, No 2, November 2021, Hal 124-134

ISSN 2685-869X (media online)

DOI 10.47065/ekuitas.v3i2.1084

Tabel 8. Output Koefisien Determinasi $\left(\mathrm{R}^{2}\right)$

\begin{tabular}{l|c|c|c|c|}
\hline Model & $\mathrm{R}$ & $\begin{array}{c}\mathrm{R} \\
\text { Square }\end{array}$ & $\begin{array}{c}\text { Adjusted } \\
\mathrm{R} \text { Square }\end{array}$ & $\begin{array}{c}\text { Std. Error of the } \\
\text { Estimate }\end{array}$ \\
\hline 1 & $0,624^{\mathrm{a}}$ & 0,389 & 0,366 & 3,186 \\
\hline
\end{tabular}

Berdasarkan Tabel 8 di atas, dapat diketahui bahwa nilai koefisien determinasi (R2) sebesar 0,389. Hal ini dapat disimpulkan Integritas (X1), Teamwork (X2) dan Employee Engagement berkontribusi 38,9\% terhadap kinerja karyawan (Y). Hal tersebut mampu menjelaskan bahwa nilai yang dihasilkan dapat berkontribusi dalam keterikatan di antara variabel Dependent dan variabel Independent.

\section{Pengujian Hipotesis}

\section{Uji - t (Parsial)}

Pengujian hipotesis dilakukan untuk mengetahui apakah variabel tersebut signifikan atau tidak. Maka, untuk mengetahui hipotesis tersebut dilakukan pengujian secara parsial yaitu dengan menguji setiap masing-masing variabel bebas terhadap variabel terikat.

Berdasarkan hasil output spss versi 24, hasil uji - t variabel Integritas (X1), Teamwork (X2) dan Employee Engagement (X3) terhadap Kinerja Karyawan (Y) adalah sebagai berikut:

Tabel 9. Output Uji Hipotesis Uji - $t$

\begin{tabular}{|c|c|c|c|c|c|c|}
\hline \multicolumn{7}{|c|}{ Coefficients $^{a}$} \\
\hline & \multirow{2}{*}{ Model } & \multicolumn{2}{|c|}{$\begin{array}{c}\text { Unstandardized } \\
\text { Coefficients }\end{array}$} & \multirow{2}{*}{$\begin{array}{c}\begin{array}{c}\text { Standardized } \\
\text { Coefficients }\end{array} \\
\text { Beta }\end{array}$} & \multirow[b]{2}{*}{$\mathrm{t}$} & \multirow[b]{2}{*}{ Sig. } \\
\hline & & B & $\begin{array}{c}\text { Std. } \\
\text { Error }\end{array}$ & & & \\
\hline \multirow[t]{4}{*}{1} & (Constant) & 1,644 & 5,745 & & 0,286 & 0,775 \\
\hline & Integritas & 0,439 & 0,094 & 0,414 & 4,667 & 0,000 \\
\hline & Teamwork & 0,221 & 0,086 & 0,228 & 2,573 & 0,012 \\
\hline & Employee Engagement & 0,383 & 0,088 & 0,390 & 4,358 & 0,000 \\
\hline
\end{tabular}

Berdasarkan tabel 9 di atas, dapat dijelaskan mengenai hasil perhitunga

Untuk variabel integritas, diperoleh thitung yang lebih besar dari ttabel $(4,667>1,990)$ dengan nilai signifikasi $(\alpha)$ kurang dari 0,05. Sehingga H0 ditolak dan H1 diterima.

a. Untuk variabel teamwork, diperoleh $t_{\text {hitung }}$ yang lebih besar dari $t_{\text {tabel }}(2,573>1,990)$ dengan nilai signifikasi $(\alpha)$ kurang dari 0,05. Sehingga $\mathrm{H}_{0}$ ditolak dan $\mathrm{H}_{1}$ diterima.

b. Untuk variabel employee engagement, diperoleh thitung yang lebih besar dari tabel $(4,358>1,990)$ dengan nilai signifikasi $(\alpha)$ kurang dari 0,05 . Sehingga $\mathrm{H}_{0}$ ditolak dan $\mathrm{H}_{1}$ diterima.

Uji - F (Simultan)

Pengujian hipotesis dilakukan untuk mengetahui apakah variabel tersebut signifikan atau tidak. Maka, untuk mengetahui hipotesis tersebut dilakukan pengujian secara simultan yaitu dengan menguji secara bersama-sama variabel bebas terhadap variabel terikat.

Berdasarkan hasil output spss versi 24 , hasil uji - F variabel Integritas $\left(\mathrm{X}_{1}\right)$, Teamwork $\left(\mathrm{X}_{2}\right)$ dan Employee Engagement $\left(\mathrm{X}_{3}\right)$ terhadap Kinerja Karyawan (Y) adalah sebagai berikut:

Tabel 10. Output Hipotesis Uji - F

\begin{tabular}{|c|c|c|c|c|c|c|}
\hline \multicolumn{7}{|c|}{$A N O V A^{a}$} \\
\hline & Model & $\begin{array}{l}\text { Sum of } \\
\text { Squares }\end{array}$ & $\mathrm{df}$ & $\begin{array}{l}\text { Mean } \\
\text { Square }\end{array}$ & $\mathrm{F}$ & Sig. \\
\hline \multirow[t]{3}{*}{1} & Regression & 510,885 & 3 & 170,295 & 16,780 & $0,000^{\mathrm{b}}$ \\
\hline & Residual & 801,742 & 79 & 10,149 & & \\
\hline & Total & 1312,627 & 82 & & & \\
\hline
\end{tabular}

a. Dependent Variable: Kinerja Karyawan

b. Predictors: (Constant), Employee Engagement, Integritas,

Teamwork 
Berdasarkan Tabel 10 di atas, hasil pengolahan SPSS 24 diperoleh nilai $F_{\text {hitung }}$ sebesar 16,780 hasil ini kemudian dibandingkan dengan $F_{\text {tabel. }}$. Dengan tingkat signifikansi $(\alpha)$ sebesar 5\% $(0,05)$, dan df : n-k-1 = 83-3-1 = 79 maka diperoleh $\mathrm{F}$ tabel sebesar 2,720. Karena nilai $\mathrm{F}_{\text {hitung }}=16,780$ lebih besar $\mathrm{F}_{\text {tabel }}=2,720$, maka $\mathrm{H}_{\mathrm{a}}$ diterima. Sehingga dapat disimpulkan bahwa terdapat pengaruh yang signifikan secara simultan antara variabel Integritas, Teamwork, dan Employee Engagement terhadap Kinerja Karyawan.

\section{Pembahasan Hasil Penelitian}

Penelitian ini telah dilakukan dengan sebaik-baiknya dan telah menggunakan prosedur metode ilmiah. Adapun pembahasan penelitian sebagai berikut:

1. Kriteria jawaban responden dapat menentukan apakah jawaban responden tersebut masuk dalam kategori Buruk Sekali, Buruk, Baik, atau Baik Sekali. Di bawah ini merupakan hasil dari jawaban responden terhadap setiap pernyataan variabel:

a. Variabel Kinerja Karyawan memiliki nilai rata-rata 3,39 yang berasumsi bahwa setiap responden yang mengisi butir pernyataan variabel kinerja karyawan dalam kategori baik, hal demikian diperkuat dengan nilai Modus yang memiliki nilai 3 yang berarti rata-rata responden yang berjumlah 83 orang menjawab mayoritas setuju untuk setiap pernyataan butir variabel kinerja karyawan. Variabel Kinerja Karyawan memiliki skor total 3380, skor minimal 996, dan skor maksimal 3984. Dalam hal ini skor total variabel kinerja karyawan berada di daerah 2988 - 3984, yang berarti skor total variabel kinerja karyawan berada dalam Kategori Baik.

b. Variabel Integritas nilai rata-rata 3,53 yang berasumsi bahwa setiap responden yang mengisi butir pernyataan variabel integritas dalam kategori baik, hal demikian diperkuat dengan nilai Modus yang memiliki nilai 4 yang berarti rata-rata responden yang berjumlah 83 orang menjawab mayoritas sangat setuju untuk setiap pernyataan butir variabel integritas. Variabel Integritas memiliki skor total 2932, skor minimal 830, dan skor maksimal 3320. Dalam hal ini skor total variabel integritas berada di daerah 2490 - 3320, yang berarti skor total variabel integritas berada dalam Kategori Baik.

c. Variabel Teamwork nilai rata-rata 3,42 yang berasumsi bahwa setiap responden yang mengisi butir pernyataan variabel teamwork dalam kategori baik, hal demikian diperkuat dengan nilai Modus yang memiliki nilai 3 yang berarti rata-rata responden yang berjumlah 83 orang menjawab mayoritas setuju untuk setiap pernyataan butir variabel teamwork. Variabel Teamwork memiliki skor total 2835, skor minimal 830, dan skor maksimal 3320. Dalam hal ini skor total variabel teamwork berada di daerah 2490 - 3320, yang berarti skor total variabel teamwork berada dalam Kategori Baik.

d. Variabel Employee Engagement nilai rata-rata 3,49 yang berasumsi bahwa setiap responden yang mengisi butir pernyataan variabel employee engagement dalam kategori baik, hal demikian diperkuat dengan nilai Modus yang memiliki nilai 3 yang berarti rata-rata responden yang berjumlah 83 orang menjawab mayoritas setuju untuk setiap pernyataan butir variabel employee engagement. Variabel Employee Engagement memiliki skor total 3474, skor minimal 830, dan skor maksimal 3320. Dalam hal ini skor total variabel employee engagement berada di daerah 2988 - 3984, yang berarti skor total variabel employee engagement berada dalam Kategori Baik.

2. Integritas $\left(\mathrm{X}_{1}\right)$ teruji berpengaruh signifikan terhadap Kinerja Karyawan (Y), ditunjukkan dengan nilai $\mathrm{t}_{\mathrm{hitung}}$ sebesar 4,667 lebih besar dari $t_{\text {tabel }}$ 1,990 menunjukkan bahwa Integritas semakin diterapkan dan dimiliki pada setiap karyawan akan membuat Kinerja Karyawan menjadi semakin meningkat dan akan tetap selalu menjalankan kebijakan yang dibuat oleh perusahaan serta patuh pada semua peraturan perusahaan.

3. Teamwork $\left(\mathrm{X}_{2}\right)$ teruji berpengaruh signifikan terhadap Kinerja Karyawan (Y), ditunjukkan dengan nilai thitung sebesar 2,573 lebih besar dari $\mathrm{t}_{\text {tabel }}$ 1,990 menunjukkan bahwa Teamwork akan menjadi faktor meningkatkan Kinerja Karyawan yang dapat berkontribusi cukup baik. Karena, dengan menerapkan teamwork pada setiap individu karyawan akan memupuk rasa kebersamaan yang sangat kuat dalam melakukan pekerjaan berat maupun ringan.

4. Employee Engagement $\left(\mathrm{X}_{3}\right)$ teruji berpengaruh signifikan terhadap Kinerja Karyawan (Y), ditunjukkan dengan nilai

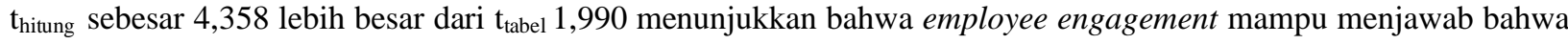
jika karyawan memiliki rasa keterikatan terhadap perusahaan / organisasi maka karyawan akan selalu senang dengan melakukan pekerjaannya, tidak menjadikan pekerjaan berat sebagai beban besar yang harus dipikul. akan tetapi, merasa dengan senang hati melakukannya dengan perasaan bangga dan bahagia karena telah bekerja pada perusahaan serta ingin bersama-sama mencapai tujuan perusahaan. Maka hal demikian sangat baik untuk Kinerja Karyawan.

5. Dari hasil uji secara simultan diketahui bahwa variabel integritas, teamwork, dan employee engagement teruji berpengaruh signifikan terhadap kinerja karyawan, ditujukan dengan nilai $F_{\text {hitung }}$ sebesar 16,780 lebih besar dari $F_{\text {tabel }}$ 2,720. Dengan tingkat signifikansi lebih kecil dari 0,05.

6. Dari persamaan regresi, terlihat bahwa nilai $\mathrm{R}$ (Koefisien Korelasi) Integritas $\left(\mathrm{X}_{1}\right)$, Teamwork $\left(\mathrm{X}_{2}\right)$ dan Employee Engagement $\left(\mathrm{X}_{3}\right)$ terhadap Kinerja Karyawan adalah 0,624. Nilai tersebut memang tidak begitu cukup besar namun dapat berpengaruh terhadap Y secara simultan. Hal tersebut mampu menjelaskan bahwa nilai yang dihasilkan dapat berkontribusi dalam keterikatan di antara variabel Dependent dan variabel Independent. 


\section{KESIMPULAN}

Berdasarkan dari hasil analisis dan pembahasan maka dapat dibuat kesimpulan hasil uji t disimpulkan bahwa secara parsial, variabel integritas, teamwork, dan employee engagement masing-masing berpengaruh signifikan terhadap kinerja karyawan. Hal ini berarti bahwa integritas semakin diterapkan dan dimiliki pada setiap karyawan akan membuat Kinerja Karyawan menjadi semakin meningkat dan akan tetap selalu menjalankan kebijakan yang dibuat oleh perusahaan serta patuh pada semua peraturan perusahaan. Teamwork akan menjadi faktor meningkatkan Kinerja Karyawan yang dapat berkontribusi cukup baik. Karena, dengan menerapkan teamwork pada setiap individu karyawan akan memupuk rasa kebersamaan yang sangat kuat dalam melakukan pekerjaan berat maupun ringan. Employee Engagement mampu menjawab bahwa jika karyawan memiliki rasa keterikatan terhadap perusahaan / organisasi maka karyawan akan selalu senang dengan melakukan pekerjaannya, tidak menjadikan pekerjaan berat sebagai beban besar yang harus dipikul. Hasil uji F, disimpulkan bahwa secara simultan variabel integritas, teamwork, dan employee engagement berpengaruh signifikan terhadap kinerja karyawan atau dengan kata lain model regesi linier berganda $\operatorname{cocok}($ fit $)$.

\section{UCAPAN TERIMA KASIH}

Penulis ucapkan terima kasih kepada segenap pihak yang telah berkontribusi baik materil maupun imateril sehingga penelitian ini berjalan dengan baik. Semoga penelitian ini memberikan sumbangan bagi khazanah keilmuan manajemen.

\section{REFERENCES}

Afandi, Pandi. 2016. Concept \& Indicator Human Resources Management For Management Research. Yogyakarta: Deepublish. Armstrong, Michael. 2014. Armstrong's Handbook Of Human Resources Management Practice. London: Kogan Page Limited. Bachtiar. 2004. Manajemen Sumber Daya Manusia. Batam: Iteraksa.

Bakker, B.A., and Leiter, P.M. 2010. Work Engagement: A Handbook of Essential Theory and Research. New York: Psychology Press.

Burn, Shawn M. 2004. Groups Theory and Practice. Canada: Thomson \& Wadsworth.

Dwi Prawani. Sri Rejeki. Dan Jefri Heridiansyah. 2013. Memahami Sebuah Konsep Integritas. Jurnal Stie Semarang. Vol 5. No. 3. Edisi Oktober 2013 (ISSN: 2252-7826).

Eva Silviani Lawasi. Boge Triatmanto. 2017. Pengaruh Komunikasi. motivasi, dan Kerjasama Tim Terhadap Peningkatan Kinerja Karyawan. Jurnal Manajemen \& Kewirausahaan Vol. 5 No.1. Malang: Universitas Merdeka Malang.

Ghozali, Imam. 2011. Aplikasi Analisis Multivariate Dengan Program SPSS. Semarang: Badan Penerbit Universitas Diponegoro

James Campbell Q. and Debra L. Nelson. 2011. Principles of Organizational Behavior. Canada: south-western College.

Jason A. Colquitt, Jeffery A. Lepine dan Michael J. Wesson. 2013. Organizational Behavior. New York : McGraw Hill.

Karina, 2013, Modul Aplikasi SPSS, Serang: Lembaga Penelitian dan Pengabdian Masyarakat (LPPM) Universitas Bina Bangsa Banten.

Kruse. 2012. What is Employee Engagement. Forbes Leadership.

Lawasi. Eva Silviani. Triatmanto, Boge. 2017. Pengaruh Komunikasi. Motivasi, dan Kerjasama Tim Terhadap Peningkatan Kinerja Karyawan. (Malang: Jurnal Manajemen. Vol. 5. No. 1)

MacLeod, D and Clarke, N. 2009. Engaging for Success: Enhancing performance through employee engagement. Department for Innovation, Business and Skills. London.

Manurung, Laurensius. 2010. Strategi dan Inovasi Model Bisnis Meningkatkan Kinerja Usaha. Jakarta: PT Gramedia.

Marciano, P.L. 2010. Carrots and Sticks Don't Work Build a Culture Employee Engagement with the Principles of RESPECT. Mexico: McGraw Hill.

Muri, Yusuf. 2014. Metode Penelitian Kuantitatif, Kualitatif, dan Penelitian Gabungan. Jakarta: Kencana.

Peterson, C. \& Selignmen, M.E. 2014. Integrity In Character Strengths and Virtues: A Hanbook And Classification. Oxford: Oxford University Press.

Petrick, J.A. and Quinn, J.F. 2000. The Integrity Capacity Construct And Moral Progress In Business. Journal Of Business Ethics. 34 (3-4). Ston: Hougton Mifflin.

Rogers, C.R. 1961. on becoming a person: a therapist's view of psychotherapy.

Schaufeli, W.B. Demerouti, E. Bakker, A.B. De Boer, E. 2003. Job demands and job resources as predictors of absence duration and frequency. Journal of Vocational Behavior. 62.

Sinambel, Lijan Poltak. 2016. Manajemen Sumber Daya Manusia. Jakarta: PT Bumi Aksara.

Suryani, Hendryani. 2015. Metode Riset Kuantitatif. Jakarta: PRENADAMEDIA Group

Tenner, A.R. dan DeToro, I.J. 1992. Total Quality Management : Three Stepps To Continuous Improvement. Reading. MA: AddisonWesley Publishing Company.

Truss, C. dkk. 2014. Employee Engagement in Theory and Practice. New York: Routledge.

Viswesvaran, Chockalingam \& Ones, Deniz S. 2000. Perspectives on Models of Job Performance. International Journal of Selection And Assessment. Vol. 8.

Yusuf, F. A. (2019). Pedoman Penulisan Skripsi dan Jurnal Ilmiah versi 0.2. Serang: Universitas Bina Bangsa.

Agatha.Christine. Panggiki, B. Lumanauw. G.G. Lumintang. 2017. Pengaruh Kompensasi. Kerjasama Tim Dan Kepuasan Kerja Terhadap Kinerja Karyawan Pada AJB Bumiputera 1912 Cabang Sam Ratulangi. (Manado: Jurnal EMBA.Vol. 5 No. 2. September)

Anggraini Sukmawati dkk.. 2015. Pengaruh Organisasi Pembelajaran dan Inovasi Terhadap Peningkatan Kinerja UMK di Kota Bogor. (Bogor: Jurnal Manajemen. Vol. XIX. No. 2. Juni) 
Ekonomi, Keuangan, Investasi dan Syariah (EKUITAS)

Vol 3, No 2, November 2021, Hal 124-134

ISSN 2685-869X (media online)

DOI 10.47065/ekuitas.v3i2.1084

Ariyandoko. Yuni. 2016. Peran Integritas Karyawan Terhadap Budaya Organisasi Pada Karyawan PT Petrokimia Gresik Departemen Personalia Dan Departemen Pendidikan Dan Pelatihan, Malang: Universitas Islam Negeri Maulana Malik Ibrahim

Hadi Sunaryo. Andi Febriyan Eka Muhti. M. Khoirul ABS. Pengaruh Kerjasama Tim dan Kreativitas Terhadap Kinerja Karyawan UD. Agro Inti Sejahtera Jember. Integritas. Jurnal Stie Semarang. Vol 5. No.3. Edisi Oktober 2013

Irvanto, Wahyu. dan Fanida, Eva Hany. 2012. Pengaruh Prinsip Akuntabilitas Terhadap Kinerja Pegawai di PT Jasa Raharja (Persero) Cabang jawa Timur. Semarang: Universitas Semarang.

Nurfajar. M. Syafiq Marzuqi. dan Nika Rohmayati. 2018. Pengaruh Employee Engagement Dan Efikasi Diri Terhadap Kinerja Karyawan PT Nikomas Gemilang Divisi PCI S5 Serang Banten. Jurnal Pengembangan Wiraswasta. Vol. 20. No. 01.

Sambudi Hamali. 2017. Pengaruh Inovasi terhadap Kinerja Bisnis Pada Industri Kecil Pakaian Jadi Kota Bandung. Jakarta

Sartono. Lidya Natalia. 2017 Pengaruh Kerja Tim Dan Organizational Learning Terhadap Kinerja Pegawai Badan Diklat Provinsi Kalimantan Barat. Kalimantan Barat: Jurnal Pendidikan.

Yusnaena. dan Sahril. 2013. Pengaruh Integritas Terhadap Kinerja Karyawan Pada Sekretariat Daerah Kabupaten Pesisir Selatan. Menara Ilmu. Vol. IX. No. 42. November 2013.

BPSDM Provinsi Riau. 2017. "Pembangunan Budaya Integritas". Pemerintah Provinsi Riau. Riau. www.bpsdm.riau.go.id (Juli 2017).

Satria. 2016. "Teori Kinerja (Pengertian, Pengukuran, Penilaian, Faktor Yang Mempengaruhi dan Tujuan Penilaian Kinerja”. Materi Belajar. Jakarta. www.materibelajar.com (21 April 2018). 